MATEC Web of Conferences 22,04016 (2015)

DOI: $10.1051 /$ matecconf/ 20152204016

(C) Owned by the authors, published by EDP Sciences, 2015

\title{
Technology Research on the Fourth Panel Mining Large Height Ful- ly-mechanized Caving Mining in Shangwan Coal Mine
}

\author{
Yingjie Liu* \\ College of Highway, Chang'an University, Xi'an, Shaanxi, China \\ Shenhua Shendong Coal Group Corporation, Shenmu, Shaanxi, China \\ Xiaomou Wang \\ College of Highway, Chang'an University, Xi'an, Shaanxi, China
}

\begin{abstract}
According to the characteristics of the 1-2 coal seam of Shangwan coal mine 4th panel, this research analyzed the feasibility of sublevel caving hydraulic support in the fully-mechanized mining face through estimation method and numerical simulation calculation. This paper also researched the several factors that affect the caving property of top-coal, such as coal thickness, coal hosting depth, top-coal joint fissure, parting condition and caving height. In the meantime, the FLAC3D was used to simulate the caving progress. The results showed that the scheme is feasible. This method cannot only guarantee the stability of coal wall but also crush the coal by the force from the mine pressure hydraulic supports.
\end{abstract}

Keywords: Shangwan coal mine; 1-2 coal seam; 4th panel; large mining height; fully-mechanized caving mining

\section{MINING CONDITIONS OF COAL SEAM}

As shown in Table 1, according the drilling results, the average coal coal seam thickness of Shangwan mine 4th panel is $8 \mathrm{~m}-9.4 \mathrm{~m}$, with the typical characteristics of shallow-buried and specially deep thickness coal seam, such as good hosting stability, higher hardness, and average $208.7 \mathrm{~m}$ buried depth. Therefore, the basic condition of sublevel caving mining technology of large height is already possessed.

Table 1. Statistical data of coal seam thickness and buried depth of 4 th panel

\begin{tabular}{|c|c|c|c|c|c|c|c|c|}
\hline \multirow{2}{*}{$\begin{array}{l}\text { Dilling } \\
\text { No. }\end{array}$} & $\begin{array}{l}\text { Thick- } \\
\text { ness }\end{array}$ & depth & \multirow{2}{*}{$\begin{array}{l}\text { Dilling } \\
\text { No. }\end{array}$} & $\begin{array}{l}\text { Thick- } \\
\text { ness }\end{array}$ & depth & \multirow{2}{*}{$\begin{array}{l}\text { Driling } \\
\text { No. }\end{array}$} & \multicolumn{2}{|c|}{ Thickness depth } \\
\hline & $\mathrm{m}$ & $\mathrm{m}$ & & $\mathrm{m}$ & $\mathrm{m}$ & & $\mathrm{m}$ & $\mathrm{m}$ \\
\hline $\mathrm{R} 46$ & 5.35 & 262.64 & lowR3 & 7.91 & 212 & b112 & 9.44 & 212.25 \\
\hline R48 & 7.05 & 261.59 & RF35 & 9.22 & 199.07 & b279 & 9.39 & 229.36 \\
\hline $\mathrm{R} 40$ & 9 & 279.2 & low 5 & 9.76 & 208.39 & R13 & 9.16 & 167.14 \\
\hline R37 & 9.67 & 276.25 & H8 & 8.41 & 201.22 & b289 & 9.03 & 156.36 \\
\hline lowR7 & 9.86 & 272.24 & R10 & 9.21 & 189.35 & R12 & 9.29 & 194.24 \\
\hline R41 & 9.7 & 243.95 & b120 & 9.62 & 193.85 & R9 & 9.25 & 168.54 \\
\hline lowR1 & 9.68 & 232 & R14 & 9.35 & 262.97 & R7 & 9.14 & 127.6 \\
\hline b212 & 9.25 & 88.41 & b283 & 7.93 & 232.32 & 168 & 9.2 & 183.85 \\
\hline b121 & 8.55 & 161.92 & b113 & 8.03 & 236.62 & R8 & 8.89 & 180.54 \\
\hline \multicolumn{2}{|c|}{ Average of thick- } & 8.9 & & Averag & depthm & 208.7 & & \\
\hline
\end{tabular}

In this research, physical experiments (such as the apparent density, real density, moisture content, natural water uptake rate) and mechanical properties(such as the uniaxial tensile strength, uniaxial compressive strength, elastic modulus, poisson ratio, changing angel sheer stress cohesion and internal friction angle)experiments were conducted. According to Platts Hardness Theory, the 1-2 coal seam $(\mathrm{f}=3.54)$ belongs to the hard coal seam. The testing is shown in the Table 2:

Table 2. Coal sample parameters data of Shangwan mine 4th panel 1-2 coal seam

\begin{tabular}{ccccccc}
$\begin{array}{c}\text { Compressive } \\
\text { strength }\end{array}$ & $\begin{array}{l}\text { Tensile } \\
\text { strength }\end{array}$ & $\begin{array}{l}\text { Elastic } \\
\text { modulus }\end{array}$ & \multirow{2}{*}{$\begin{array}{l}\text { Poisson } \\
\text { ratio }\end{array}$} & Cohesion & $\begin{array}{l}\text { Internal } \\
\text { friction } \\
\text { angle }\end{array}$ \\
\cline { 1 - 3 } & $\mathrm{MPa}$ & $\mathrm{GPa}$ & & $\mathrm{MPa}$ & \\
\hline 35.43 & 2.38 & 3.94 & 0.33 & 4.5 & 38 \\
\hline
\end{tabular}

\section{ADOPTING FULL-MECHANIZED SUPPORT} FEASIBILITY ANALYSIS

In order to test support strength, the analysis is conducted by the estimation method and the numerical simulation calculation. The present sublevel caving hydraulic support is sheltered by low positon support with two cylinders that the type is ZFY12500/25/39D. This kind of support has support strength of $1.33-1.35 \mathrm{MPa}$, suiting for caving height of $3.5 \mathrm{~m}$.

\subsection{Calculated by estimation method}

The support strength is calculated by estimation

*Corresponding author: 290785858@,qq.com

This is an Open Access article distributed under the terms of the Creative Commons Attribution License 4.0, which permits unrestricted use, distribution, and reproduction in any medium, provided the original work is properly cited. 


\section{MATEC Web of Conferences}

method, which based on the weight hydraulic support taken from the caving roof rock and balanced the dynamic load which is caused by basic roof instability. The equation is shown as follows:

$q=K_{d}\left(q_{c}+q_{r c}\right)$

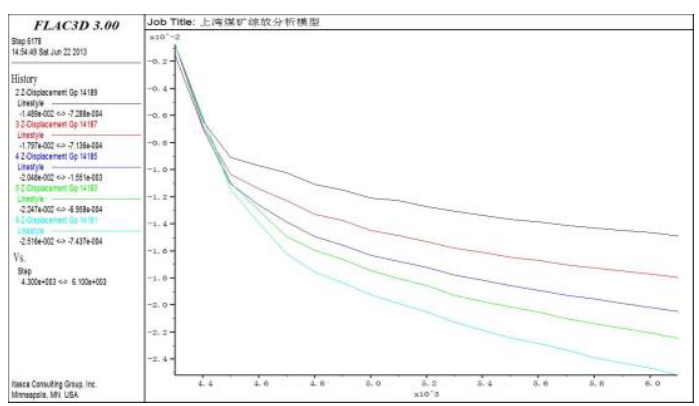

(a) $0.6 \mathrm{MPa}$

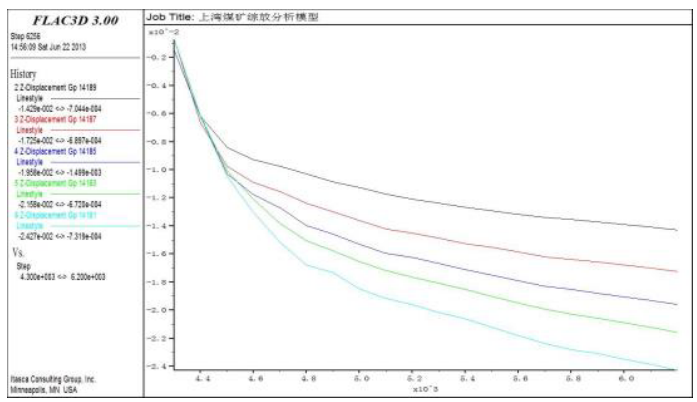

(b) $0.7 \mathrm{MPa}$

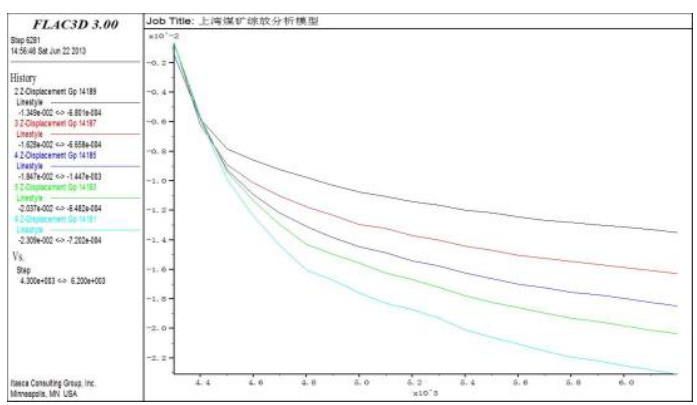

(c) $0.8 \mathrm{MPa}$

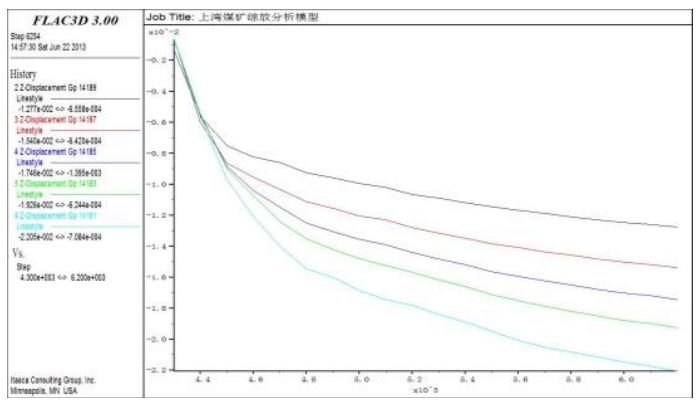

(d) $0.9 \mathrm{MPa}$

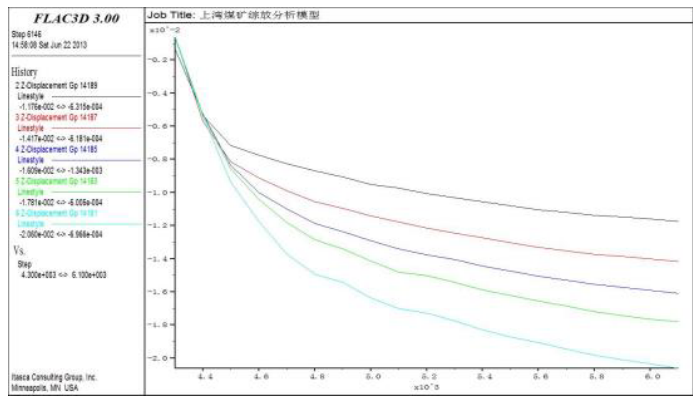

(e) $1.0 \mathrm{MPa}$

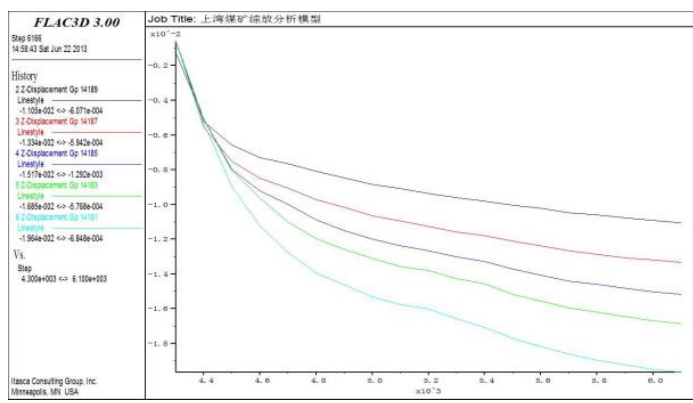

(f) $1.1 \mathrm{MPa}$

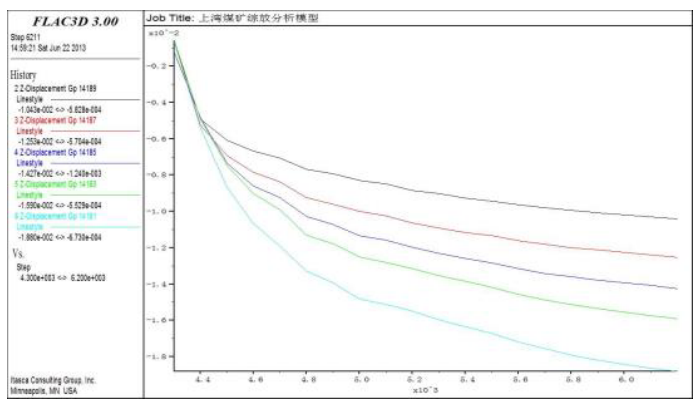

(g) $1.2 \mathrm{MPa}$

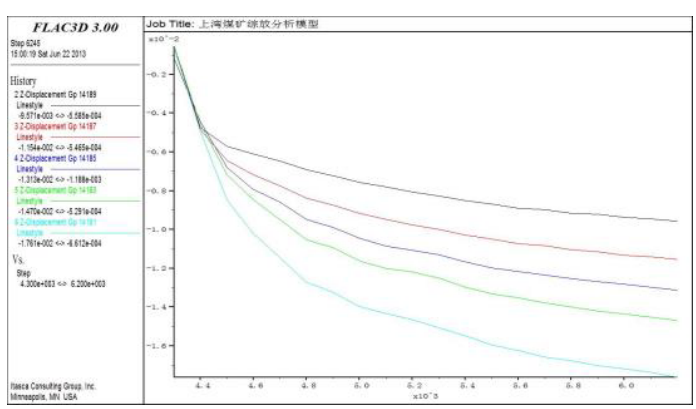

(h) $1.3 \mathrm{MPa}$

Where $q$ is the support strength (Mpa) that hydraulic support needs; $K_{d}$ is the dynamic load coefficient when the basic roof instability occurs. According to the statistic results of mine pressure from sublevel caving mining face, $K_{d}$ is generally 1.1-1.8. Referring to the data collected from Liuta Mine, Buertai Mine, Daliuta Mine, $K_{d}$ is 1.3 which was used in this re- 
search; $q_{c}$ is the gravity stress of rock, $q_{c}=\gamma_{r c} h, \gamma_{r c}$ is the of roof rock which takes the value of $25 \mathrm{kN} / \mathrm{m}^{3}$. The loose coefficient and the coal recovery respectively take the value of 1.2 and $82.87 \%$. The goaf would be fully filled when the roof caving height reached $36.88 \mathrm{~m} . q_{r c}$ is the gravity stress of roof coal upon hydraulic support, $q_{r c}=\gamma_{r c} M_{d}$, and $\gamma_{r c}$ is the bulk density of roof coal. Its value is $14.7 \mathrm{kN} / \mathrm{m}^{3}$.

The support strength is $1.3 \mathrm{MPa}$ which is a result from the above equation.

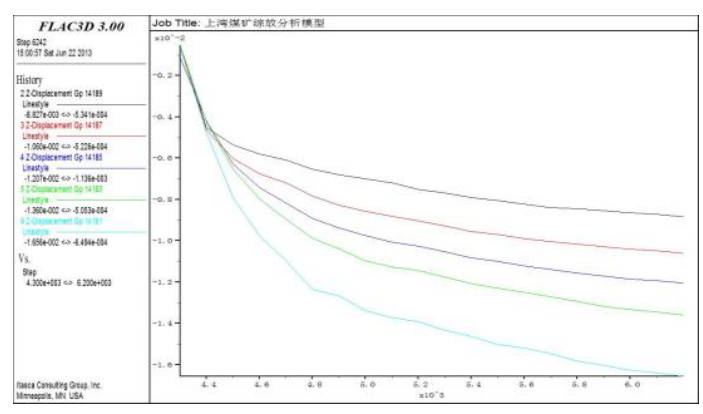

(i) $1.4 \mathrm{MPa}$

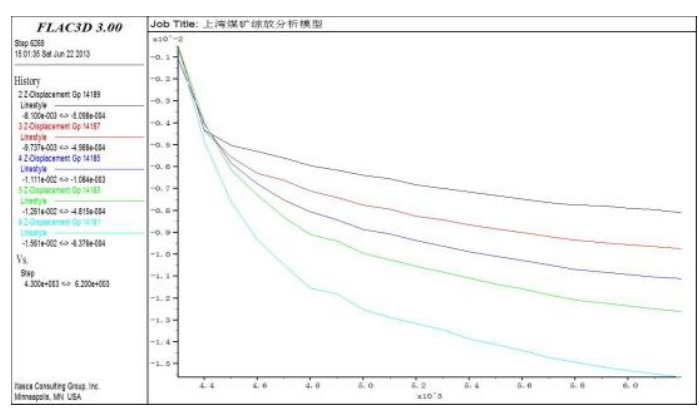

(j) $1.5 \mathrm{MPa}$

Figure 2. Displacement of top coal subsidence and roof control stage relational graph

\subsection{Calculated by numerical simulation}

Based on the coal hosting condition, numerical simulation software was used to build the model to calculate. Consider the different law under different conditions, 10 experiments was respectively stimulated with the support strength $\mathrm{P}=0.6 \mathrm{MPa}, 0.7 \mathrm{MPa}, 0.8 \mathrm{MPa}$, $0.9 \mathrm{MPa}, 1.0 \mathrm{MPa}, 1.1 \mathrm{MPa}, 1.2 \mathrm{MPa}, 1.3 \mathrm{MPa}, 1.4 \mathrm{MPa}$, $1.5 \mathrm{MPa}$. From the above experiments, the law between the top coal and the support strength was obtained. As shown in Figure 2, different support strengths have different subsidence displacement. The 5 curves is the monitoring position of $1 \mathrm{~m}, 2 \mathrm{~m}, 3 \mathrm{~m}, 4 \mathrm{~m}$ and $5 \mathrm{~m}$ respectively on coal wall.

From the Figure 2, the greater supporting strength, the slower and smaller the subsidence is. Therefore, increasing the supporting strength can better control the top roof. The subsidence displacement is increased as the time increases not due to the support strength. In Figure 3, it was mapped the largest subsidence displacements based on different support strengths that were counted:

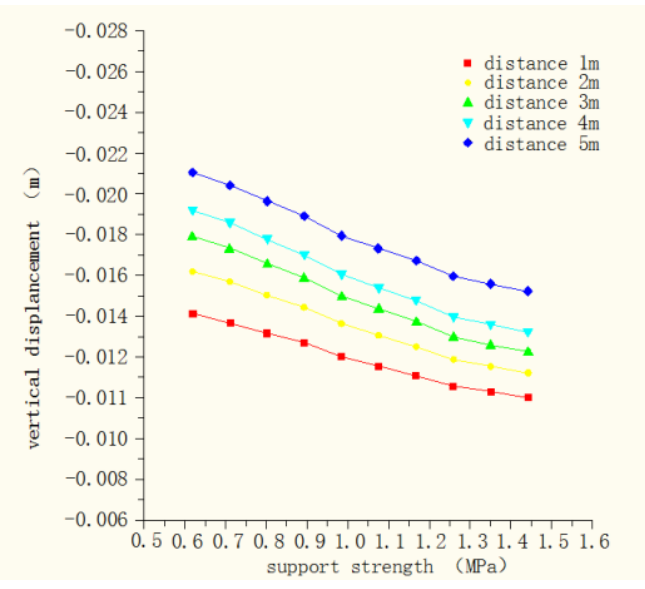

Figure 3. Support strength and displacement of top coal subsidence relational graph

Some information can be read from the Figure 3, the decreasing trend as the support strength increases. The increasing support strength can significantly prevent the subsidence of roof coal when the support strength is less than $1.3 \mathrm{Mpa}$. It is used to prevent ability from becoming weaker and it is gradually stable when the support strength is greater than $1.3 \mathrm{Mpa}$. The subsidence displacement reached a smaller value at this moment. Therefore, the value $1.3 \mathrm{Mpa}$ is a threshold for support. In conclusion, the support strength should be set above 1.3MPa in this mining face.

\subsection{Working resistance of support to be determined}

The equation (2) shows the calculation of working resistance based on matching size and empty-support distance.

$$
P=q\left(L_{K}+L_{D}\right) B
$$

$P$ is the working resistance $(\mathrm{kN}) ; q$ is the support strength which is $1.3 \mathrm{MPa} ; L_{K}$ is the empty-support distance which is $0.4 \mathrm{~m} ; L_{D}$ is the length of support top beam; $B$ is the width of support which is $1.75 \mathrm{~m}$.

The working resistance is $11375 \mathrm{kN}$ calculated from the above equation. Consequently, the support strength of ZFY12500/25/39D is $1.33 \mathrm{MPa}-1.35 \mathrm{MPa}$, which can meet the support demands of the cutting height of $3.5 \mathrm{~m}$ for the large height sublevel caving mining.

\section{TOP COAL CAVIBILITY THEORY ANALYSIS}

Full-mechanized caving mining success or failure is determined by the top coal cavibility which is one of the key factors. As the inherent property of top coal in fully-mechanized top coal mining, cavibility is the metrics which reveals the degree of difficulty of top coal caving and releasing under support pressure, 


\section{MATEC Web of Conferences}

namely, it's the synthesis of the characteristics of top coal caving and releasing. Having good cavibility is a necessary condition for full-mechanized caving mining. To adopt corresponding measures and technological parameter according to the difference of the cavibility of top coal is the basis of achieving the advantage of caving coal mining.

\subsection{Coal seam strength influence on top coal cavibil- ity}

As Figure 4 shows, the relationship of uniaxial compressive strength $\left(R_{c}\right)$, binding force coefficient $(C)$ and internal friction angle is shown as follows:

$\operatorname{Sin} \phi=\frac{\frac{R_{\mathrm{c}}}{2}}{\frac{R_{\mathrm{c}}}{2}+C \llbracket \operatorname{ctg} \phi}=\frac{R_{\mathrm{c}}}{R_{\mathrm{c}}+2 C \operatorname{ctg} \phi}$

$R_{\mathrm{c}}=R_{\mathrm{c}} \sin \phi+2 C\lceil\cos \phi$ obvious when $\phi$ is certain, and $R_{c}$ will be increased with the increase of $C$. However, when $C$ is constant, the derivative of formula 4 can be obtained as follows:

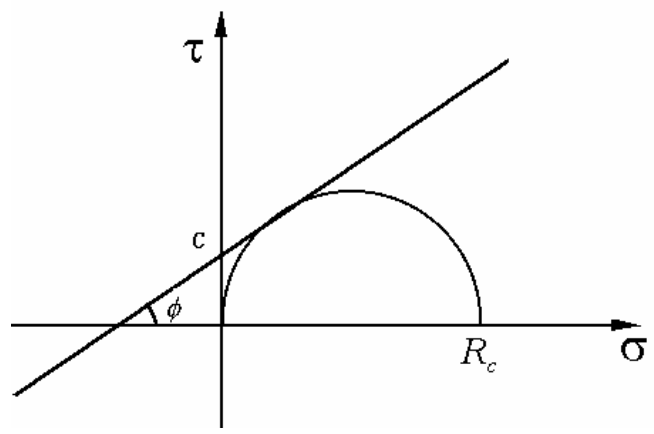

Figure 4. Coal Mechanical Parameter Relationship

$$
\begin{aligned}
& \frac{d R_{\mathrm{c}}}{d \phi}=\frac{-2 C \sin \phi(1-\sin \phi)+2 C \sqsubset \cos ^{2} \phi}{(1-\sin \phi)^{2}} \\
& =\frac{2 C\left(\sin ^{2} \phi+c \cos ^{2} \phi-\sin \phi\right)}{(1-\sin \phi)^{2}}=\frac{2 C}{1-\sin \phi}
\end{aligned}
$$

By the formula can be obtained $\frac{2 C}{1-\sin \phi}>0$

According to the quality of functions, $\phi$ is in $(0, \pi / 2)$ domain, formula 5 is a monotone increase. In other words, when $C$ is constant, the uniaxial compressive strength $\left(R_{c}\right)$ will be increased with the increase of internal friction angle $\phi$; to the contrary, when the uniaxial compressive strength $\left(R_{c}\right)$ is increased, the binding force coefficient or the internal friction angle will be increased. Therefore, the uniaxial compressive strength represents the corresponding responsiveness of coal body to some extent.

The uniaxial compressive strength of coal seam has impacts on the process and the level of the breaking of top coal under the pressure, so it is strong or moderate association with top-coal caving angle. According to field observation of full-mechanized caving faces, when uniaxial compressive strength is increased, namely, the top-coal is hard and the top-coal caving angle is smaller. According to caving movement rule of top coal, when top-coal caving angle is smaller, it's a disadvantage for the output of top coal. Figure 4 reflects the relationship of uniaxial compressive strength of coal seam and the breaking of top coal.

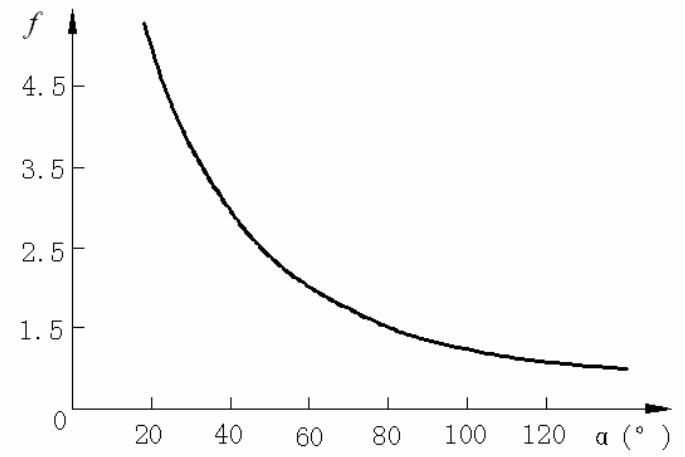

Figure 5. Coal seam hardness coefficient and top coal caving angle relationship

As Figure 5 shows, according to 1-2 top coal seam mechanical parameters $f=3 \sim 4$, the measurements from laboratory is $f=3.54$, and the top-coal caving angle is about $40^{\circ}-30^{\circ}$

When calculated that the coal seam mining thickness is $8.9 \mathrm{~m}$, the coal cutting height is $6.0 \mathrm{~m}$, and the breadth from top beam rear-ends of full-mechanized support to scraper blade is $3.5 \mathrm{~m}$, so the reasonable caving angle of top coal should be not less than a:

$a=\arctan \frac{8.9-6}{3.5}=39.6^{\circ}$

According to the above equation to be calculated, most of top-coal caving angles are smaller than reasonable caving angles, so the caving movement rule of top coal which relatively lags behind, is a disadvantage for the recovery of top coal.

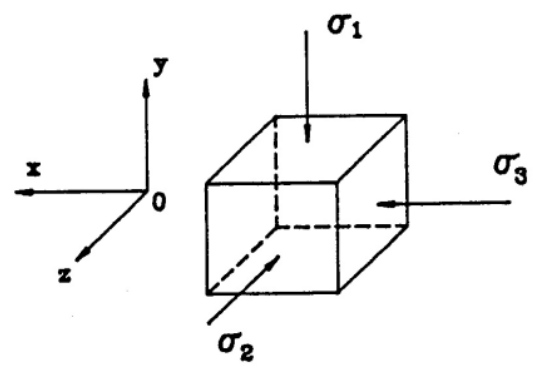

Figure 6. Unit stress condition of top coal 
3.2 Coal seam depth influence on caving ability of top coal

The coal seam depth $(H)$ directly influences on the magnitude of original rock stress $(\gamma H)$, at the same time, it also influences the intensity of stop face rock bearing pressure peak $(K \gamma H)$. Without considering the effects of tectonic stress field, Figure 6 shows the stress state of coal wall in front of the top coal unit cell because of the function of mining abutment pressure $(K \gamma H)$.

Top coal caving stope, the unit within the top-coal body is in three-dimensional pressure state $\left(\sigma_{1}, \sigma_{2}\right.$, $\left.\sigma_{3}\right)$. According to Griffey theory, there is:

$\sigma_{1}=\sigma_{3} \frac{\sqrt{1+f^{2}}+f}{\sqrt{1+f^{2}}-f}+R_{\mathrm{c}}$

In this formula, when $\sigma_{1}$ is the first main stress, $\sigma_{1}$ is (MPa); when $\sigma_{3}$ is the third main stress, $\sigma_{3}=\lambda^{\prime} \gamma H(\mathrm{MPa}) ; R_{c}$ is the uniaxial compressive strength (MPa); $f$ is the coefficient of internal friction, and it's generally obtained that $f=0.7$.

$\frac{H}{R_{\mathrm{c}}}=\frac{1}{\gamma\left(K-\lambda n \frac{\sqrt{1+f^{2}}+f}{\sqrt{1+f^{2}}-f}\right)}$

When it meets the formula 5 , the top coal has the broken strength. Put $\sigma_{1}=K \gamma H$ and $\sigma_{3}=\lambda^{\prime} \gamma H$ into formula 6 , we can obtain as follows:

$$
\begin{aligned}
& \frac{H}{R_{\mathrm{c}}}=\frac{1}{\gamma\left(K-\lambda n \frac{\sqrt{1+f^{2}}+f}{\sqrt{1+f^{2}}-f}\right)} \\
& \text { Assume that } \quad \frac{\mu}{1-\mu}, \mu \text { is the poisson ratio of coal, }
\end{aligned}
$$

$1-2$ coal seam $\mu=0.33$. Put it into formula 8 , the derivative of formula 7 is obtained as follows:

$$
\frac{H}{R_{\mathrm{c}}}=\frac{1}{\left[\gamma\left(K-n \frac{\mu}{1-\mu} \frac{\sqrt{1+f^{2}}+f}{\sqrt{1+f^{2}}-f}\right)\right]}
$$

Formula 8 is the proportional relationship of coal seam depth $(H)$ and strength of coal mass $\left(R_{\mathrm{c}}\right)$. put $K=3.5$, the bulk density of top roof coal seam $\gamma$ $=2.5 \mathrm{t} / \mathrm{m} 3$ and other parameters into formula 8 , the derivative of formula 9 is obtained.

When the strength of coal mass $\left(R_{\mathrm{c}}\right)$ is certain, other parameters are static to make the top coal body complete the break based on the influence of abutment pressure, so the coal seam depth $(H)$ needs to meet the formula as follows:
$H \geq 23.8 R_{\mathrm{c}}$

According to the formula, it can be obtained that when $\mathrm{H}$ is bigger, it's easier to meet the critical condition of failure; when the critical condition is better, and the better effect of top coal breaking can reflect the better top coal cavibility. The 1-2 coal seam body is counted by average uniaxial compressive strength, $R_{\mathrm{c}}=35.4 \mathrm{MPa}$. The demanding burial depth of full-mechanized caving mining is $841.52 \mathrm{~m}$, and the $1-2$ coal seam burial depth is about $208.7 \mathrm{~m}$, it is relatively different from the full-mechanized caving mining of coal seam depth requirements.

\subsection{Top coal joint crack influence on caving ability of top coal}

Generally speaking, the rock masses contained varying level of geological weak-side and construction. According to the analysis of 1-2 histograms of drilling hole and field investigation, it is a weakness for the integrity, the joint crack which is dense, and the caving ability which is better; however, it is an advantage for using fully-mechanized coal caving mining.

\subsection{Coal seam dirt band influence on caving ability}

It is a complex coal seam dirt band influence on caving ability, and it is related to the impact, the properties of rock parting (hardness), the thickness of layers, and the number of layers and positions in space. Proved by practice, the impact largely depends on the thickness of single layer dirt band when the single layer dirt band is thicker than $300 \mathrm{~mm}$. The coal caving ability depends on the property of dirt band. Geological data shows 1-2 coal seam with a stable horizon, simple construction, small change of thickness, which is generally without dirt band. It can be seen that the condition of coal seam dirt band has no influence on caving ability.

\subsection{Roof conditions influence on top coal caving ability}

The coal seam roof includes two parts, the immediate roof and the main roof. Full-mechanized caving mining demands mining with caving the minimum thickness of immediate roof is shown as follows:

$\Sigma h_{\min }=M / K_{\mathrm{p}}$

$\Sigma h$ is mining with caving the sum of the thickness of coal seams (m); $M$ is the height of coal mining (m); $K_{\mathrm{p}}$ is bulking factor, which is generally 1.25 .

Based on the obtained formula, the mining height is 8.9 (which is the average thickness) in 1-2 coal seam. When the bulking factor is 1.25 , the full-mechanized caving mining that demands the minimum immediate roof thickness is $7.12 \mathrm{~m}$. Count the drilling roof in first recovery mining face, the roof conditions are advantages to the release of top coal when the thickness of immediate roofs (including false roofs) are $7.49 \mathrm{~m}$, $14.28 \mathrm{~m}, 15.26 \mathrm{~m}$, and $7.16 \mathrm{~m}$. 
3.6 Mining and caving height influence on top coal caving ability

The ratio of mining height to caving height is the ratio of fully mechanized caving faces caving coal height to coal cutting height, and the influence on top coal caving ability reaction includes two aspects: one is repeating support of foreset act on top coal fragmentation, and the other is the mining height influence on top coal caving space Only fully broken caving can effectively recover.

The requirement for coal fully broken caving is shown as follows:

$M-h^{\prime}=k_{\mathrm{s}} m_{\mathrm{f}}$

Plug $M=m_{\mathrm{g}+} m_{\mathrm{f}}, K=m_{\mathrm{f}} / m_{\mathrm{g}}$ in the type above, obtains:

$$
K=\frac{m_{\mathrm{g}}-h^{\prime}}{m_{\mathrm{g}}\left(k_{\mathrm{s}}-1\right)}
$$

In this formula, $k_{\mathrm{s}}$ is the coefficient of coal fully broken caving.

As we can see, when the result of the ratio of mining height to caving height of working face calculation, the top coal that won't be fully broken is bad for top coal. Calculate by shearer coal cutting height is $6.0 \mathrm{~m}$, the coal opening height of support is $1 \mathrm{~m}$ (low place coal stent strip ), the coefficient of coal fully broken caving is 1.2 , so the ratio of mining height to caving height can't be bigger than 1:4.17. Caving ratio is 1 : 0.48 . If the average of $1-2$ coal seam is $8.9 \mathrm{~m}$, the cutting height that meets requirement of mining height to caving height is fully broken for top coal. The cutting height is $6.0 \mathrm{~m}$, and the thickness of top coal is $2.9 \mathrm{~m}$. It is satisfied the top coal caving ratio of $68^{\text {th }}$ (the regulation of security in coal mine).

According to the analysis mentioned earlier, the full-mechanized caving mining cavibility have four categories in China, and indexes and evaluating results are shown in Table 3:

Table 3. Cavibility indexes of evaluation results

\begin{tabular}{|c|c|c|c|}
\hline No. & factors & results & $\begin{array}{l}\text { Classify of } \\
\text { cavibility }\end{array}$ \\
\hline 1 & $\begin{array}{l}\text { the strength of } \\
\text { coal seams }\end{array}$ & IV & \\
\hline 2 & depth & IV & \\
\hline 3 & joint fracture & II & \\
\hline 4 & $\begin{array}{l}\text { influence of } \\
\text { rock parting }\end{array}$ & no effect & III \\
\hline 5 & $\begin{array}{l}\text { Condition of } \\
\text { top roof }\end{array}$ & II & \\
\hline 6 & mining height & I & \\
\hline
\end{tabular}

According to the analysis mentioned earlier, the 1-2 coal seam top coal is low intactness and the joint fracture that developed well is good for top coal recovery. However, because the strength of top coal is large, the lagged caving is possible. After overall evaluation, the cavibility of this coal seam belongs to the third kind.
4 MODEL ANALYSIS OF TOP COAL CAVIBILITY

Because the top coal cavibility is generally increasing the coal cutting height, reducing the thickness of top coal, it depends on the way of repeated supporting to break the top coal when using large mining height full-mechanized caving mining that can increase the recovery of top coal.

According to the above analysis, build up analytical models to analyze the condition of top coal breaking when the thickness of top coal decrease, the height of cutting coal is up to $6.0 \mathrm{~m}$, and the thickness of top coal is $2.9 \mathrm{~m}$.

This model considers open-off cut which is $10 \mathrm{~m}$, push $130 \mathrm{~m}, 10 \mathrm{~m}$ in each time, and 13 times in total. As shown in Figure 7, this is the breaking condition of top roof pushing $130 \mathrm{~m}$.

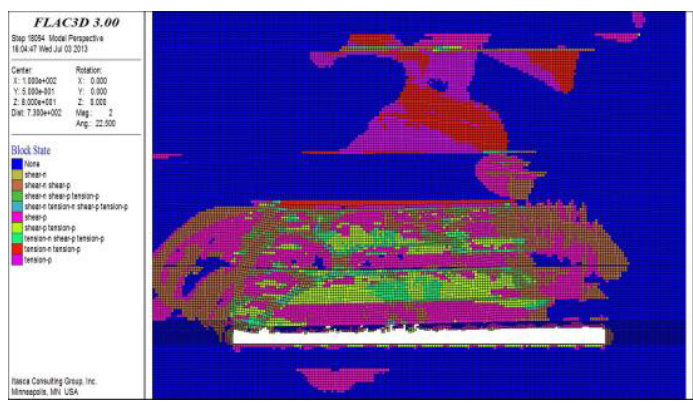

Figure 7. Top roof top coal push $130 \mathrm{~m}$ breaking phase diagram

As shown in Figure 7, the coal wall stability is good, and the broken boundary of coal wall in advance remains relatively stable. Under the influence of mine pressure, when top coal is $0.5 \mathrm{~m}-1 \mathrm{~m}$, it can be broken caving to satisfy the releasing condition. However, if the broken boundary of mine pressure is greater than $2 \mathrm{~m}$, we can see from the model that the roof is fully caving, and the thickness of top coal which is $2 \mathrm{~m}-3 \mathrm{~m}$ can be fully caving.

\section{CAPACITY AND RECOVERY ANALYSIS}

The recovery of working face need to reach $86.7 \%$, and the recovery of top coal is $66 \%$. If the length of working face is $300 \mathrm{~m}$, the size of section pillar is $20 \mathrm{~m}$; the width of two gate way is $5 \mathrm{~m}$; the height of gate way is $3.5 \mathrm{~m}$; the recovery of gate way is $39.3 \%$, and the recovery of mining area is $80 \%$ (without considering the recovery of section pillar). Analogy analysis shows that it can be realized.

The recovery of top coal is considered as $70 \%$, the recovery of working face can reach $88.2 \%$, so the recovery of mining area is $81.37 \%$. To count it by 16 cuts/days, the daily output of working face can reach 47910.8t. Consider that as 330 days, the annual output can reach 1581 million tons. 
ICETA 2015

Table 4. Recovery of working face in different recovery of top coal statistical table

\begin{tabular}{|c|c|c|c|c|c|c|}
\hline $\begin{array}{l}\text { Methods of cosal } \\
\text { mining.1 }\end{array}$ & $\begin{array}{c}\text { Thickness of cosl } \\
\text { seams } / \mathrm{m} .\end{array}$ & $\begin{array}{l}\text { Height of coal } \\
\text { cutting. }\end{array}$ & $\begin{array}{c}\text { Recovery of cosl } \\
\text { cutting. }\end{array}$ & $\begin{array}{l}\text { Thickness of } \\
\text { cosl-caving } / \mathrm{m} .\end{array}$ & $\begin{array}{l}\text { Recovery of } \\
\text { coal-caving. }\end{array}$ & $\begin{array}{l}\text { Recovery of } \\
\text { working face. }\end{array}$ \\
\hline $\begin{array}{l}\text { Full-mechanizad } \\
\text { caving mining. }\end{array}$ & 8.9 .1 & 3.5 .1 & $97 \% .1$ & 5.4 .1 & $50 \%$ & $68.48 \%$ \\
\hline $\begin{array}{l}\text { Full-mechanized } \\
\text { caving mining. }\end{array}$ & 8.9 .1 & 3.5.1 & $97 \%$. & 5.4 .1 & $55 \%$ & $71.25 \%$ \\
\hline $\begin{array}{l}\text { Full-mechanized } \\
\text { caving mining. }\end{array}$ & 8.9 .1 & 3.5 .1 & $97 \%$. & 5.4 .1 & $60 \%$ & $74.55 \%$ \\
\hline $\begin{array}{l}\text { Full-mechanized } \\
\text { caving mining. }\end{array}$ & 8.9 .1 & 3.5 .1 & $97 \%$ & 5.4 .1 & $65 \%$ & $77.58 \%$ \\
\hline $\begin{array}{l}\text { Full-mechanized } \\
\text { caving mining. }\end{array}$ & 8.9 .1 & 3.5 .1 & $97 \%$ & 5.4 .1 & $70 \%$ & $80.62 \%$ \\
\hline $\begin{array}{l}\text { Full-mechanizad } \\
\text { caving mining. }\end{array}$ & 8.9 .1 & 4.1 & $97 \%$ & 4.9 .1 & $50 \%$ & $71.12 \%$ \\
\hline $\begin{array}{l}\text { Full-mechanized } \\
\text { caving mining. }\end{array}$ & 8.9 .1 & 4.1 & $97 \% .1$ & 4.9 .1 & $55 \%$ & $73.88 \%$ \\
\hline $\begin{array}{l}\text { Full-mechanized } \\
\text { caving mining. }\end{array}$ & 8.9 .1 & 4.1 & $97 \% .1$ & 4.9 .1 & $60 \%$ & $76.63 \%$ \\
\hline $\begin{array}{l}\text { Full-mechanized } \\
\text { caving mining.1 }\end{array}$ & 8.9 .1 & 4.1 & $97 \%$ & 4.9. & $65 \%$ & $79.38 \%$ \\
\hline $\begin{array}{l}\text { Full-mechanized } \\
\text { caving mining. }\end{array}$ & 8.9 .1 & 4.1 & $97 \% .1$ & 4.9 .1 & $70 \%$ & $82.13 \%$ \\
\hline $\begin{array}{l}\text { Full-mechanized } \\
\text { caving mining. }\end{array}$ & 8.9 .1 & 5.1 & $97 \%$. & 3.9 .1 & $50 \%$ & $76.4 \%$ \\
\hline $\begin{array}{l}\text { Full-mechanizad } \\
\text { caving mining. }\end{array}$ & 8.9 .1 & 5. & $97 \%$ & 3.9 .1 & $55 \%$ & $78.6 \%$ \\
\hline $\begin{array}{l}\text { Full-mechanized } \\
\text { caving mining. }\end{array}$ & 8.9 .1 & 5.1 & $97 \% .1$ & 3.9 .1 & $60 \%$ & $80.79 \%$ \\
\hline $\begin{array}{l}\text { Full-mechanized } \\
\text { caving mining. }\end{array}$ & 8.9 .1 & 5.1 & $97 \% .1$ & 3.9.1 & $65 \%$ & $82.98 \%$ \\
\hline $\begin{array}{l}\text { Full-mechanized } \\
\text { caving mining. }\end{array}$ & 8.9 .1 & 5.1 & $97 \%$. & 3.9 .1 & $70 \%$ & $85.17 \%$ \\
\hline $\begin{array}{l}\text { Full-mechanized } \\
\text { caving mining. }\end{array}$ & 8.9 .1 & 6.1 & $97 \%$. & 2.9 .1 & $50 \%$ & $81.69 \%$ \\
\hline $\begin{array}{l}\text { Full-mechanized } \\
\text { caving mining. }\end{array}$ & 8.9 .1 & 6.1 & $97 \%$. & 2.9. & $55 \%$ & $83.31 \%$ \\
\hline $\begin{array}{l}\text { Full-mechanized } \\
\text { caving mining. }\end{array}$ & 8.9 .1 & 6.1 & $97 \%$ & 2.9 .1 & $60 \%$ & $84.94 \%$ \\
\hline $\begin{array}{l}\text { Full-mechanized } \\
\text { caving mining. }\end{array}$ & 8.9 .1 & 6.1 & $97 \%$ & 2.9 .1 & $65 \%$ & $86.57 \%$ \\
\hline $\begin{array}{l}\text { Full-mechanized } \\
\text { caving mining. }\end{array}$ & 8.9 .1 & 6.1 & $97 \%$. & 2.9 .1 & $70 \%$ & $88.2 \%$ \\
\hline $\begin{array}{l}\text { High cut in fully } \\
\text { mechanized coal } \\
\text { mining.r }\end{array}$ & 8.9 .1 & 7.1 & $97 \%$ &. & י. & $76.3 \%$ \\
\hline $\begin{array}{l}\text { High cut in fully } \\
\text { mechanized cosl } \\
\text { mining. }\end{array}$ & 8.9 .1 & 8. & $97 \% .1$ & י. & י. & $87.2 \%$ \\
\hline
\end{tabular}

As we know, the recovery of top coal is key index to success if using full-mechanized caving mining of great mining height. Several mining methods of recovery comparison analysis are shown in Table .

The analysis of Table 4 shows, if use high cut in full-mechanized caving mining height of coal cutting is $6 \mathrm{~m}$, the caving ratio is lower than before, so the recovery of top coal is about to reach more than $70 \%$. The recovery of working face reaches $88.2 \%$ when the recovery of top coal is $70 \%$. According to existing equipment, it will reach high recovery rate of fully mechanized. At the same time, the recovery rate will exceed in the recovery rate of great cutting height which is $8 \mathrm{~m}$

\section{CONCLUSION}

(1) According to the cavibility of 1-2 coal seam, it usually uses deep hole blasting weaken top coal technology and related measures to improve the cavibility of the coal seam.

(2) Using full-mechanized caving mining feasibility analysis through 1-2 coal seam. Considered from technology, the cavibility of 1-2 coal seam is normal, the ordinary high cut in fully mechanized coal mining is not suitable. But research results show that the fully mechanized coal mining uses the height of coal cutting which is $6 \mathrm{~m}$ can not only keep coal wall stability but also rely on mine ground pressure and repeat supporting to break the top coal to realize high cut in fully mechanized coal. Analysis shows it can reach or ex- 


\section{MATEC Web of Conferences}

ceed the level of recovery of top coal in height which is $8 \mathrm{~m}$ when large mining height which is $6 \mathrm{~m}$ is broken by the top-coal recovery rate of $70 \%$

(3) According to existing technology level, the analysis of the factors of high cut in fully mechanized coal mining project and summarizing is shown in Table 5.

Table 5. High cut in fully mechanized coal mining project analysis statement

\begin{tabular}{ll}
\hline Items & $\begin{array}{l}\text { High cut in fully mechanized } \\
\text { coal mining }\end{array}$ \\
\hline $\begin{array}{l}\text { Technical feasibility } \\
\begin{array}{l}\text { Equipment feasibility } \\
\text { System whether need to } \\
\text { reform }\end{array}\end{array}$ & $\begin{array}{l}\text { Feasible } \\
\text { Capacity }\end{array}$ \\
$\begin{array}{l}\text { Mining recovery rate } \\
\text { Whether can use the existing }\end{array}$ \\
equipment
\end{tabular}$\quad$\begin{tabular}{l}
1581 million t/a \\
\hline
\end{tabular}

\section{REFERENCES}

[1] Yongqi Xu. 2009. Coal Ming. China Mining University Press, 116-132.

[2] Yong Yuan, Shihao Tu. \& Ying Wang. 2010. Discussion on the key problems and solutions of large mining height fully mechanized mining technology. Coal Science and Technology, 38(1): 4-8.

[3] Qingxiang Huang. 2000. Shallow buried coal seam long wall mining roof structure and strata control research. China Mining University Press, 50-72.

[4] Mengjiao Lv. 2010. The long arm of the stope underground pressure behavior and support type choice in Shendong mining area. Coal science and technology, 39(12): 34-45.

[5] Jianping Zuo, Hongbao Zhao, Jianli Yang. \& Ruidong Peng. 2013. High cut in fully mechanized coal mining coal rock caving law numerical simulation research. 41(1): 56-59.

[6] Qiang Zhou. 2012. Steep seam top coal caving pre blast weakening technology research. The innovation and development of fully mechanized top coal caving technology theory and practice- The 30 anniversary of the fully mechanized top coal caving technology. Beijing: Press of Coal Industry, 598-602.

[7] Lingpu Zhu. \& Shaohong Yan. 2012. Based on FLAC3D working face of the top coal movement law of large mining height fully mechanized research. The innovation and development of fully mechanized top coal caving technology theory and practice- The 30 anniversary of the fully mechanized top coal caving technology. Beijing: Press of Coal Industry, 426-432. 